\title{
Pemberdayaan Kelompok PKK Melalui Keterampilan Olah Pangan Yoghurt Sinbiotik Untuk Mendukung Gaya Hidup Sehat dan Mendorong Perekonomian di Masa Pandemi Covid-10
}

\author{
Anisa Nurina Aulia*, Ara Nugrahayu Nalawati, Ahib Asadam, Aisyah Yuristianti, Rizki \\ Rismawati \\ Universitas Muhammadiyah Jember \\ email: anisa_nurina@unmuhjember.ac.id,aranugrahayu@unmuhjember.ac.id, \\ ahibassadam@unmuhjember.ac.id
}

Diterima: April 2021 | Dipublikasikan: Juni 2021

\begin{abstract}
ABSTRAK
Pandemi Covid-19 di Indonesia menimbulkan masalah baru tidak hanya bagi sektor kesehatan, tetapi juga dari sektor ekonomi. Salah satu desa terdampak adalah Desa Kemuning Lor, Kecamatan Arjasa, Kabupaten Jember dimana sebagian besar masyarakat yang memproduksi buah naga merah dan penghasil susu sapi segar mengeluhkan penurunan jumlah produk yang terjual sehingga mengakibatkan terjadinya penurunan omset. Oleh karena itu, perlu upaya pemberdayaan masyarakat untuk memberikan pengetahuan mengenai pengolahan susu segar dan buah naga merah yang dapat diolah menjadi bahan bernilai ekonomi lebih tinggi, seperti yogurt sinbiotik ekstrak buah naga merah.. Berdasarkan hasil evaluasi, Ibu-ibu di Desa Kemuning Lor, yaitu mendapatkan informasi yang jelas terkait kegiatan pemberdayaan masyarakat dari segi pengetahuan, keterampilan, dan ekonomi.Kegiatan pemberdayaan masyarakat dapat menciptakan lapangan pekerjaan baru yang berasal dari pengembangan industri komoditas yang berada di sekitar lingkungan warga. Ibu-ibu peserta pelatihan memperoleh informasi yang rinci terkait langkah pengembangan iklim usaha dengan mengolah buah naga merah dan susu sapi segar menjadi yogurt sinbiotik ekstrak buah naga merah. Tahap pemberdayaan berikutnya yaitu pendampingan proses pengemasan menjadi produk minuman ready to drink yang memiliki daya tarik bagi masyarakat umum, serta pendampingan promosi produk yogurt sinbiotik ekstrak buah naga merah menjadi ikon Desa Kemuning Lor yang berada pada kawasan wisata Rembangan.
\end{abstract}

Kata Kunci: susu sapi segar, buah naga merah, yogurt sinbiotik,

\section{ABSTRACT}

The Covid-19 pandemic in Indonesia has caused new problems not only for the health but also for the economy. One of the affected villages is Kemuning Lor, Arjasa, Jember Regency. Most of the people there who produced the dragon fruit and milk cows have complained about their products being sold and causing a decrease in turnover. So there is a need for community empowerment efforts to provide knowledge about the processing of dragon milk and fruit that can be processed into higher economic value products, for example, dragon fruit extract synbiotic yogurt. Based on the results of the evaluation, several practical benefits were obtained by the mothers in Kemuning Lor, They were getting clear information related to empowerment activities which about knowledge, skills, and economics. the empowerment activities can create new jobs from the development of the commodity industry in the vicinity of residents. The training participants received an information deeply regarding steps to develop a business climate by processing red dragon fruit and fresh milk. The next stage of empowerment is assistance the packaging process of a syinbiotic yoghurt into a ready-to-drink beverage products that are attractive to the general public, and promoting synbiotic red dragon fruit extract's yoghurt, to become the icon of Kemuning Lor Village, which take a place as the tourism Area.

Keywords: Milk cow, red dragon fruit, synbiotic yogurt

\section{PENDAHULUAN}


Kebutuhan susu sapi di Indonesia mengalami peningkatan setiap tahun. Hal ini belum didukung produksi susu sapi yang hanya mampu memenuhi produksi sebesar $21 \%$ dari konsumsi nasional, sedangkan sisanya sebesar $79 \%$ berasal dari impor. Nilai angka tersebut mengindikasikan bahwa agribisnis sub sektor peternakan sapi perah masih menyimpan permasalahan kompleks dari sektor hulu hingga hilir (Kementerian Pertanian, 2016). Sentra populasi sapi perah tertinggi di Indonesia adalah Jawa Timur, hampir 50\% populasi sapi perah di Indonesia berada di Provinsi Jawa Timur.Hal tersebut mengindikasikan bahwa sebagian besar wilayah di Provinsi Jawa Timur cocok untuk peternakan sapi perah.Sebagian besar wilayah di Provinsi Jawa Timur memiliki lahan penghijauan yang cukup untuk mengembangbiakan sapi perah, salah satunya yaitu di Kabupaten Jember.

Produksi susu sapi perah di Kabupaten Jember cukup melimpah ditandai dengan total produksi per tahun mencapai 2,981 juta liter per/tahun (BPS, 2017). Namun para peternak hanya menjual susu sapi dalam keadaan segar. Peternak sapi perah sering mengeluhkan harga susu sapi segar yang masih rendah yaitu berkisar Rp 10.000,-/liter sehingga hasil penjualan hanya dapat memberikan sedikit keuntungan yang sebagian besarnya digunakan untuk pembiayaan produksi. Kemunculan pandemi COVID-19 di Indonesia menimbulkan masalah baru bagi pelaku usaha susu sapi perah di Kabupaten Jember. Beberapa masalah yang muncul tidak hanya dari aspek kesehatan namun juga dari aspek ekonomi. Dari aspek ekonomi, pelaku usaha sapi perah di Kabupaten Jember mengeluhkan bahwa masa pandemi COVID-19 menyebabkan tidak semua susu sapi segar bisa terjual sehingga terjadi penurunan omset sebesar 60\% (Jatimnet, 2020). Susu sapi segar yang belum mengalami proses pengolahan bersifat mudah mengalami kerusakan. Oleh karena itu, diperlukan upaya untuk bisa meningkatkan nilai ekonomi dan daya simpan dari susu sapi segar dengan mengolah menjadi beberapa produk olahan berbahan dasar susu.

Yogurt merupakan salah satu produk olahan susu sapi yang memanfaatkan hasil metabolisme Bakteri Asam Laktat (BAL). BAL yang umum digunakan untuk pembuatan yogurt ada dua macam, yaitu Lactobacillus bulgaricus dan Streptococcus thermophiles (Tamime dan Robinson, 2007). Selain itu, yogurt juga bermanfaat bagi penderita lactose intolerance sebagai alternatif pengganti susu, peningkatan kekebalan, dan pencegahan gangguan gastrointestinal kesehatan (Weerathilake, 2014). Yogurt sebagai sumber probiotik saat ini semakin digemari setelah dikombinasi dengan berbagai macam perisa dan pewarna. Namun pemakaian perisa dan pewarna buatan oleh industri kimia dikhawatirkan akan menghilangkan fungsinya sebagai makanan kesehatan. Fungsi probiotik sebagai makanan fungsional haruslah dipertahankan bahkan harus ditingkatkan. Pemakaian ekstrak buah naga merah dapat digunakan sebagai sumber pewarna dan sebagai prebiotik alami.

Menurut Wichienchot et al. (2010), buah naga merah mengandungan karbohidrat yang terdiri dari glukosa, fruktosa, dan oligosakarida. Oligasakarida berperan sebagai prebiotik di dalam tubuh. Kandungan oligosakarida yang terdapat pada buah naga merah berjumlah 89,6 g/kg yang terdiri dari raffinosa, stakiosa, dan fruktooligosakarida. Selain itu, oligosakarida menunjukkan ciri sebagai prebiotik yang memiliki ketahanan terhadap kondisi asam pada perut manusia, ketahanan sebagian terhadap $\alpha$-amilase manusia, serta memiliki kemampuan untuk merangsang pertumbuhan Lactobcillus casei dan Bifidobacterium. Oleh karena itu, buah naga merah merupakan sumber potensial dari prebiotik yang dapat digunakan sebagai bahan dalam pangan fungsional dan produk nutreatical.Sehingga buah naga merah merupakan sumber potensial dari prebiotic yang dapat digunakan sebagai ingredient dalam pewarna pada yogurt.

Pencampuran antara yogurt sebagai sumber probiotik dan buah naga merah sebagai sumber prebiotik disebut yogurt sinbiotik, yang merupakan salah satu pangan fungsional yang bermanfaat untuk masyarakat.Pengolahan bahan makanan menjadi pangan fungsional ini menjadi sangat penting di masa pandemi covid-19 karena dengan mengkonsumsi sumber probiotik dan prebiotik dapat meningkatkan imunitas tubuh manusia.Ditinjau dari aspek ekonomi, pangan fungsional dapat dikembangkan menggunakan manajemen bisnis yang tepat sehingga dapat menjadi sumber perbaikan ekonomi masyarakat.

Desa Kemuning Lor di Kecamatan Arjasa merupakan salah satu sentra pengembangan buah naga merah dan susu sapi perah di Kabupaten Jember. Selama ini, warga sebatas memanen buah naga merah 
tanpa melakukan pengolahan lebih lanjut sehingga ketika produksi buah naga merah mengalami puncak panen dan jumlah produksi melebihi permintaan pasar, maka buah naga merah menjadi tidak laku hingga mengalami kebusukan dan petani mengalami kerugian.Selain penghasil buah naga merah, Desa Kemuning Lor juga merupakan daerah yang berpotensi sebagai tempat pengembangan usaha sapi perah karena letaknya yang berada pada dataran tinggi sehingga sangat cocok untuk usaha ternak sapi perah.Jumlah produksi susu sapi di desa ini cukup besar, tetapi susu yang diproduksi hanya di jual berupa susu segar, belum ada pengolahan susu yang dapat meningkatkan ekonomi masyarakat, terlebih di masa pandemi covid-19 yang membuat harga susu murni jatuh dan banyak yang tidak laku. Berdasarkan fakta di lapang, perlu adanya upaya pemberdayaan masyarakat untuk memberikan pengetahuan mengenai pengolahan susu dan buah naga merah yang dapat diolah menjadi bahan pangan fungsional yaitu yogurt sinbiotik ekstrak buah naga merah.

Pemberdayaan masyarakat ini bekerjasama dengan mitra, yaitu PKK Desa Kemuning Lor, dimana ibu-ibu Desa Kemuning Lor mewakili rumah tangga penghasil buah naga dan peternak susu sapi. Pemberdayaan Ibu-ibu PKK di desa tersebut masih tergolong sebagai tenaga kerja produktif sehingga kegiatan pemberdayaan ini sangat penting dilakukan. Kegiatan pemberdayaan ini bertujuan untuk menumbuhkan kesadaran dan kemandirian dalam berwirausaha, sekaligus sebagai alternatif lapangan kerja guna meningkatkan pendapatan keluarga dalam usaha mencapai keluarga yang bahagia dan sejahtera. Untuk ibu-ibu ini mencari pekerjaan untuk membantu ekonomi keluarga tergolong sulit karena rata-rata hanya lulusan SMP dan SMA, sedangkan kebutuhan sehari-hari keluarga terus mengalami peningkatan pengeluaran. Walaupun demikian, diyakini sangat banyak kemampuan yang dimiliki kaum ibu-ibu tersebut dalam meningkatkan kesejahteraan keluarga. Kegiatan ini diharapkan dapat menambah keterampilan ibu-ibu PKK dalam mengolah susu dan mengekstrak buah naga dengan memproduksi yoghurt sinbiotik buah naga merah. Diharapkan keterampilan membuat yoghurt sinbiotik ekstrak buah naga merah ini dapat dikembangkan secara profesional dengan manajemen bisnis pengolahan yang baik sehingga dapat menghasilkan produk yang bernilai ekonomis tinggi dan membantu perekonomian petani buah naga dan peternak sapi perah di Desa Kemuning Lor, Kecamatan Arjasa, Kabupaten Jember.

\section{METODE PEIAKSANAAN}

Pemberdayaan kelompok PKK di Desa Kemuning Lor dilaksanakan pada bulan JanuariMaret 2021 dengan menerapkan strategi khusus.Strategi tersebut berupa pendekatan, komunikasi, dan pendampingan. Ilustrasi metode pemberdayaan masyarakat yang dilakukan tim pelaksana dapat dilihat pada Gambar 1. Pada tahap awal pelaksanaan kegiatan pengabdian diperlukan pengumpulan beberapa dokumen serta perencanaan kegiatan sebagai berikut: pembuatan dokumen perizinan dan formulir kerjasama mitra untuk pelatihan dan pendampingan, pemantapan rencana pelatihan, pembuatan format evaluasi, observasi ke lokasi, dan pembelian peralatan untuk pendampingan.

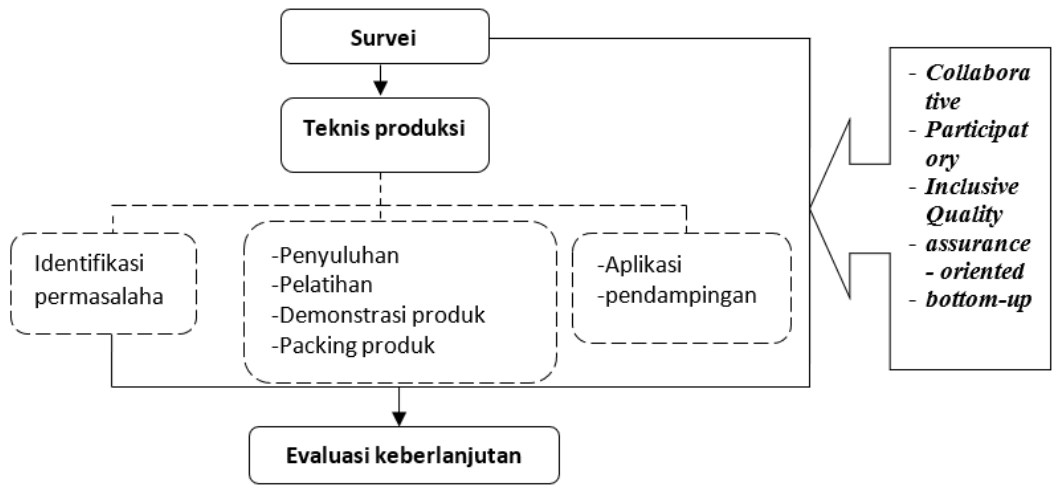

Gambar 1 Metode pelaksanaan dan pendekatan kegiatan pengabdian

Selanjutnya, teknis produksi yang berkaitan pada pelaksanaan langsung kegiatan pengabdian dengan memberikan metode edukasi kepada masyarakat khususnya anggota PKK 
melalui penyuluhan masyarakat, pelatihan dan demonstrasi, serta praktek dan pendampingan langsung bersama pihak-pihak terkait (anggota PKK, perangkat desa, dan pengelola PKK) dalam mengolah produk yoghurt sinbiotik hingga mengemas menjadi minuman ready to drink. Tahap akhir pendampingan yaitu dilakukan evaluasi yang bertujuan untuk mengetahui seberapa jauh efektifitas kegiatan pengabdian yang dapat dimanfaatkan oleh warga Desa Kemuning Lor dalam mengoptimalkan produk komoditi di sekitar lingkungan warga.

\section{HASIL KEGIATAN}

Kegiatan pengabdian di Desa Kemuning Lor ini merupakan salah satu kegiatan tri dharma yang dilaksanakan oleh dosen dan mahasiswa.Implementasi kegiatan pembelajaran di kelas maupun laboratorium kemudian masyarakat dapat merasakan manfaat dan hasil penelitian merupakan tujuan dari kegiatan tri dharna sebagaiupaya peningkatan kesejakteraan masyarakat, terutama masyarakat di Kabupaten Jember. Kecamatan Arjasa merupakan salah satu sentra pengembangan buah naga dan susu di Kabupaten Jember, terutama Desa Kemuning Lor. Desa Kemuning Lor Kecamatan Arjasa Kabupaten Jember merupakan daerah dengan keadaan geografis yang sangat mendukung untuk pengembangan komoditas buah naga. Buah naga yang berasal dari daerah tersebut dikenal lebih manis daripada daerah lainnya. Luas wilayah Desa Kemuning Lor adalah 1.145 Ha, luas lahan yang dominan adalah lahan pertanian yaitu seluas 637,25 Ha. Berdasarkan luas lahan yang ada sekitar 245,63 Ha dimanfaatkan untuk tanaman buah naga (Profil Desa Kemuning Lor, 2015).

Kegiatan pengabdian pembuatan yougurt sinbiotik dilakukan di kediaman kader masyarakat pembina ibu-ibu kelombok wanita PKK vaitu Ibu Winarni.

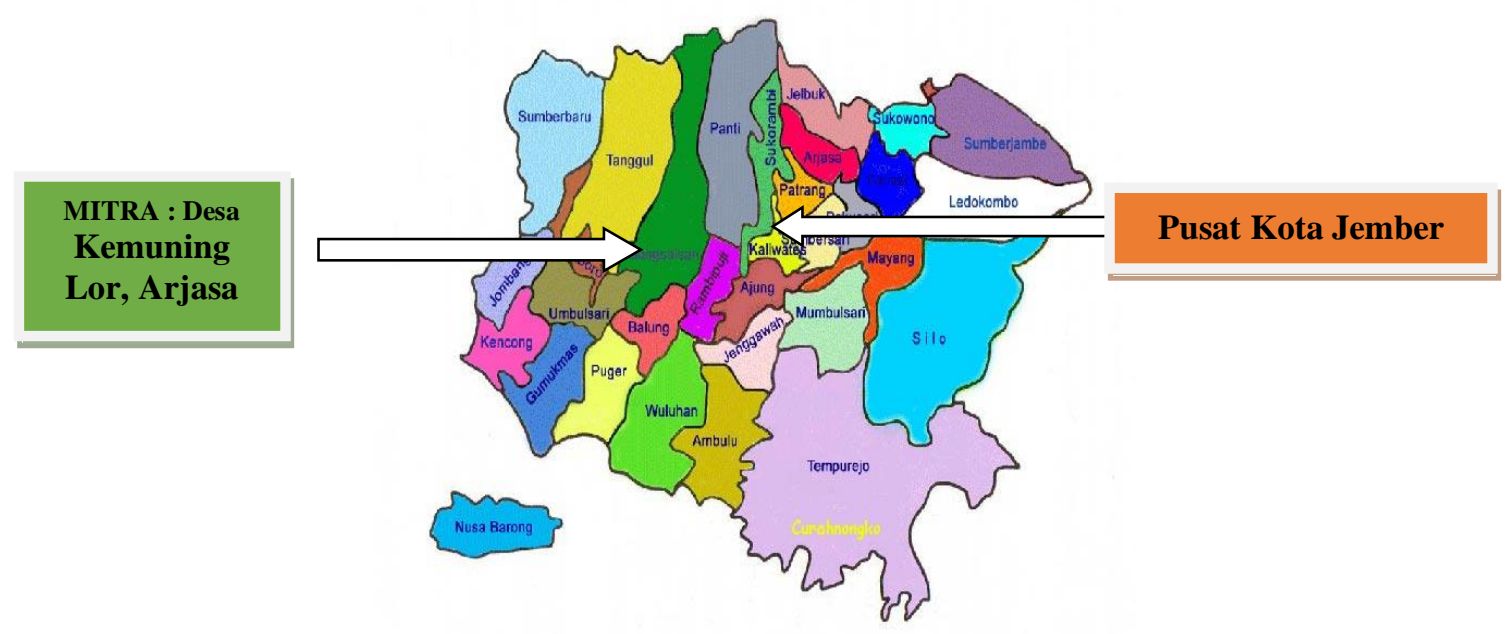

Gambar 2 Peta lokasi Desa Kemuning Lor dari pusat Kota Jember

Tahapan kegiatan pengabdian di Desa Kemuning Lor diadakan pada bulan Januari-Maret 2021 dapat dilihat pada Tabel 1 berikut: 
Tabel 1 Tahapan kegiatan pengabdian

\begin{tabular}{|c|c|c|}
\hline No & Uraian Tahapan Kegiatan & Metode Pendekatan yang Ditawarkan \\
\hline 1 & $\begin{array}{l}\text { - Identifikasi permasalahan mitra dan } \\
\text { - Pesiapan alat dan bahan }\end{array}$ & $\begin{array}{l}\text { - Alat: timbangan, termometer, kompor gas, } \\
\text { mangkuk, sendok/pisau, panci, gelas/botol, } \\
\text { blender } \\
\text { - Bahan: susu segar } 1 \mathrm{~L} \text {, buah naga } 500 \mathrm{~g} \text {, starter } \\
\text { yogurt (Lactobacillus sp.), gula, dan air }\end{array}$ \\
\hline 2 & Penyuluhan & $\begin{array}{l}\text { Memberi informasi, pengetahuan, wawasan } \\
\text { penggunaan starter yang digunakan dalam } \\
\text { pembuatan yogurt sinbiotik. Material tambahan } \\
\text { disediakan dengan teknologi aplikasi. }\end{array}$ \\
\hline 3 & Pelatihan dan demonstrasi & $\begin{array}{l}\text { Melakukan pelatihan bersama terhadap alat dan } \\
\text { bahan pembuatan yogurt sinbiotik dan interaksi } \\
\text { antara tim pelaksana dan mitra. }\end{array}$ \\
\hline 4 & Pelatihan packing product & $\begin{array}{l}\text { Tutorial pembuatan kemasan yang menarik dan } \\
\text { praktik langsung. }\end{array}$ \\
\hline 5 & Aplikasi & $\begin{array}{l}\text { Aplikasi di lapangan meliputi kegiatan } \\
\text { pendampingan pembuatan yogurt sinbiotik menjadi } \\
\text { minuman ready to drink yang dilakukan oleh dosen } \\
\text { dan dibantu mahasiswa sehingga para anggota } \\
\text { PKK lebih memahami dan terampil dalam } \\
\text { prosesnya. }\end{array}$ \\
\hline
\end{tabular}

Penentuan permasalahan mitra ditentukan bersama-sama antara tim pengusul dengan mitra yang dilakukan dengan cara diskusi. Identifikasi awal yang ditemukan pada mitra "PKK Desa Kemuning Lor", antara lain:belum memiliki keterampilan dalam pengolahan susu sapi segar pada pada ibu-ibu PKK, kurangnya inovasi dalam memproduksi makanan dan minuman yang bergizi, kurangnya pengetahuan penerapan manajemen bisnis yang tepat sehingga semua produksi buah naga dan susu sapi segar memiliki nilai jual yang tinggi. Pada Tabel 2akan dijelaskan analisis permasalahan beserta solusi yang bisa diterapkan pada produk yogurt sinbiotik di Desa Kemuning Lor.

Tabel 2 Analisis permasalahan di Desa Kemuning Lor

\begin{tabular}{|c|c|c|}
\hline Penyebab & Dampak & Alternatif solusi \\
\hline $\begin{array}{l}\text { 1. Kurangnya } \\
\text { pengetahuan } \\
\text { pengolahan susu sapi } \\
\text { segar dan buah naga } \\
\text { merah } \\
\text { 2. Kurang memahami } \\
\text { manajemen bisnis dan } \\
\text { pemasaran produk } \\
\text { agroindustri }\end{array}$ & $\begin{array}{l}\text { 1. Produk buah naga ketika panen } \\
\text { raya banyak yang tidak terjual dan } \\
\text { membusuk sehingga masyarakat } \\
\text { merugi } \\
\text { 2. Angka produksi dan } \\
\text { pemasaran susu murni dimasa } \\
\text { pandemi mengalami } \\
\text { penurunan } \\
\text { 3. Teknik pemasaran yang } \\
\text { masih konvensional karena hanya } \\
\text { mengandalkan pembeli yang lewat }\end{array}$ & $\begin{array}{l}\text { 1. Pelatihan pengolahan pasca } \\
\text { panen susu sapi segar } \\
\text { dengan membuat yogurt } \\
\text { sinbiotik ekstrak buah naga } \\
\text { merah } \\
\text { 2. Pelatihan teknologi } \\
\text { pengemasan yoghurt } \\
\text { sinbiotik ekstrak buah naga } \\
\text { merah } \\
\text { 3. Pelatihan manajemen bisnis } \\
\text { dan pemasaran yogurt } \\
\text { sinbiotik }\end{array}$ \\
\hline
\end{tabular}

Permasalahan yang dihadapi mitra membutuhkan kolaborasi dan kerjasama dari berbagai pihak. Dalam menentukan persoalan dibutuhkan kesepakatan dari tim pengusul maupun mitra dengan cara diskusi secara terarah. Sharing menjadi kata kunci dalam diskusi sehingga mitra dapat mengungkapkan persoalan yang dialami dengan terbuka. Bebeerapa upaya yang dilakukan bersama untuk menyelesaikan permasalahan mitra selama pelaksanaan program Pemberdayaan Kelompok PKK di Desa Kemuning Lor adalah sebagai berikut:

\section{1) Pelatihan penanganan pasca panen dengan membuat yogurt sinbiotik ekstrak buah naga merah}

Pembuatan yogurt sinbiotik berbasis susu sapi segar yang telah mengalami fermentasi dikombinasi dengan ekstrak buah naga merah sebagai sumber prebiotik dan sebagai pigmen alami untuk memanfaatkan buah naga merah yang diperoleh dari perkebunan warga di Desa 
Kemuning Lor. Pengolahan yogurt sinbiotik bertujuan untuk memberikan nilai tambah pada produk susu sapi segar dan buah naga merah, serta dapat menambah umur simpan produk sehingga produk olahan susu ini lebih tahan lama. Pada proses pembuatan yogurt sinbiotik harus memperhatikan kualitas bahan baku. Tahapan pembuatan yogurt sinbiotik ekstrak buah naga merah sebagai berikut:
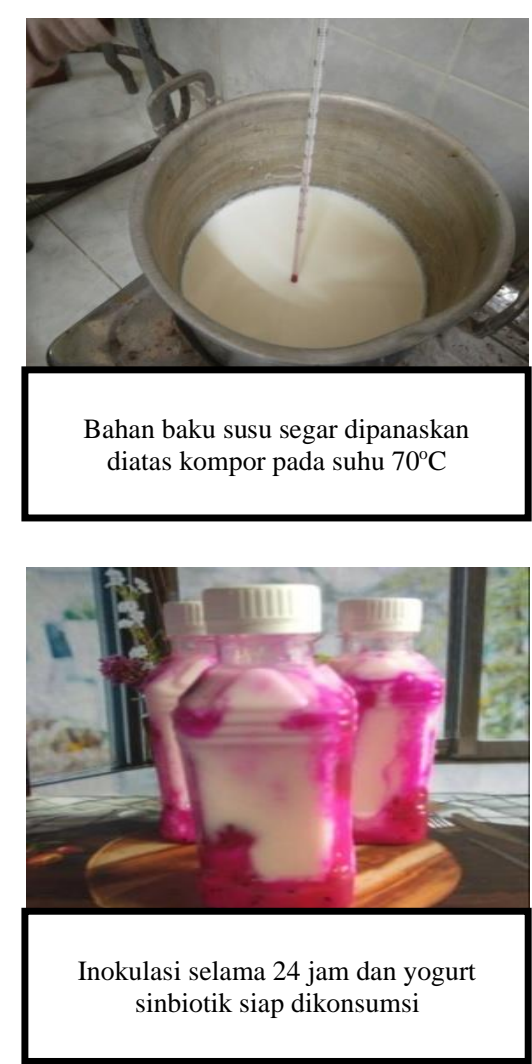

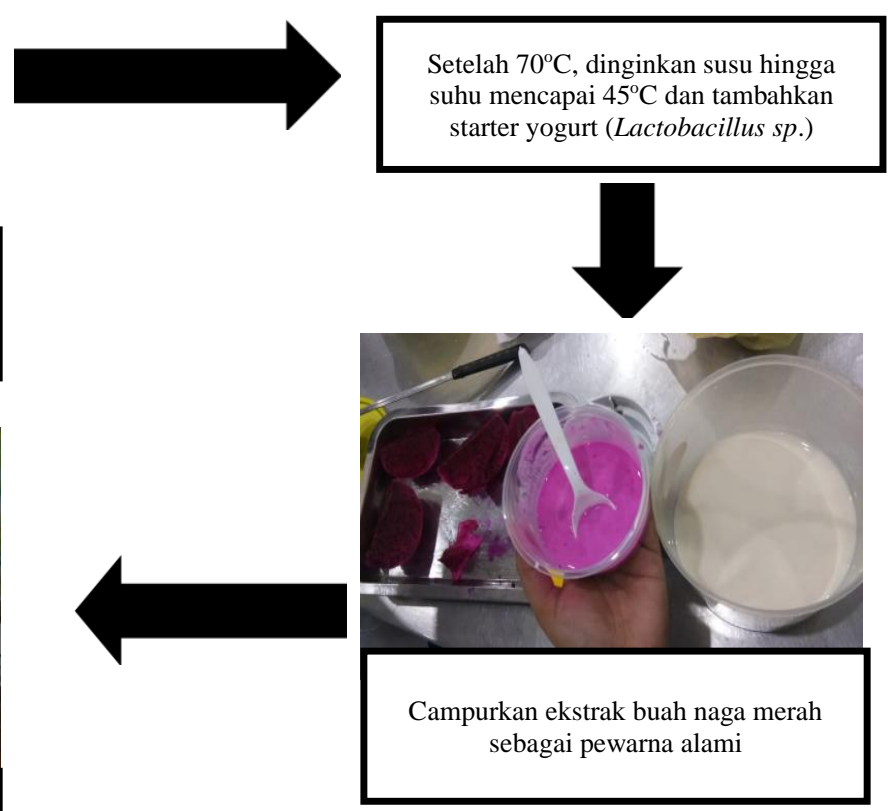

Gambar 3 Proses pembuatan yogurt sinbiotik buah naga merah

\section{2) Pelatihan teknik produksi yogurt sinbiotik secara sederhana}

Pengolahan yogurt sinbiotik menggunakan peralatan sangat sederhana yang umumnya ada di rumah warga. Selain kualitas bahan utama yang harus segar, peralatan memasak juga harus dalam keadaan bersih dan steril. Kemudian dilanjutkan dengan tahap pembuatan ekstrak buah naga dan pengolahan susu murni menjadi yogurt.

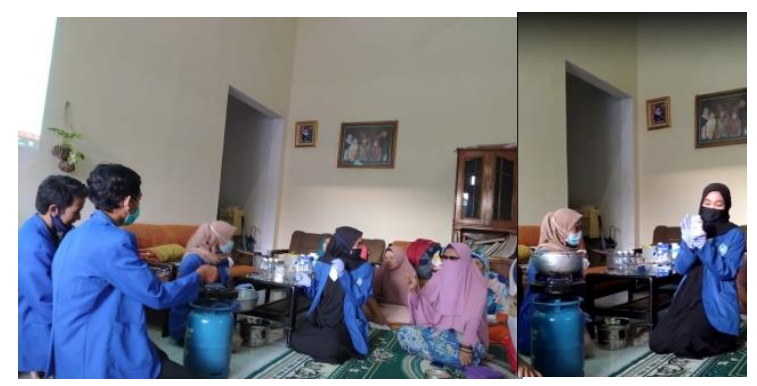

Gambar 4 Mahasiswa prodi Agribisnis dan Teknologi Industri Pertanian menjelaskan pembuatan yogurt sinbiotik kepada kelompok Ibu-ibu PKK Desa Kemuning Lor

\section{3)Pelatihan teknologi pengemasan dan penyimpanan produk yogurt sinbiotik}

Dalam upaya meningkatkan nilai jual dan menjaga kualitas serta keamanan yogurt sinbiotik, maka mitra harus memahami cara pengolahan dan pengemasan produk secara 
higienis sehingga nilai gizi tetap terjaga. Beberapa syarat yang harus dipenuhi dalam mendesain kemasan produk bahan pangan, antara lain:

a. Pengemas berfungsi sebagai tempat/wadah.

b. Pengemas dapat melindungi kualitas dan mutu suatu produk sehingga pengemas dapat melindungi produk baik pada saat penyimpanan di gudang, saat proses pengangkutan, hingga berada di tangan konsumen. Pengemas bertujuan untuk mempertahakan kualitas agar lebih terjamin.

c. Pengemas harus praktis, mudah dibawa, mudah dibuka dan ditutup kembali, serta ringan dan menarik.

d. Ketepatan ukuran disini yaitu suatu perusahaan harus memperhatikan antara kemasan produk dengan kemampuan daya beli konsumen.

e. Pengemas dapat memberikan nilai tambah. Pengemas yang menarik dapat meningkatkan nilai tambah terhadap produk itu sendiri.

f. Pengemas harus berisi informasi produk dan promosi. Kemasan yang digunakan sebaiknya tidak hanya sekedar pembungkus tanpa identitas, melainkan harus mengandung informasi dan prospek pelayanan usaha ataupun barang yang dijual. Informasi yang tercantum berupa nama usaha dan alamat pusat maupun cabang. Prospek layanan misalnya sales, service, dan aksesoris.

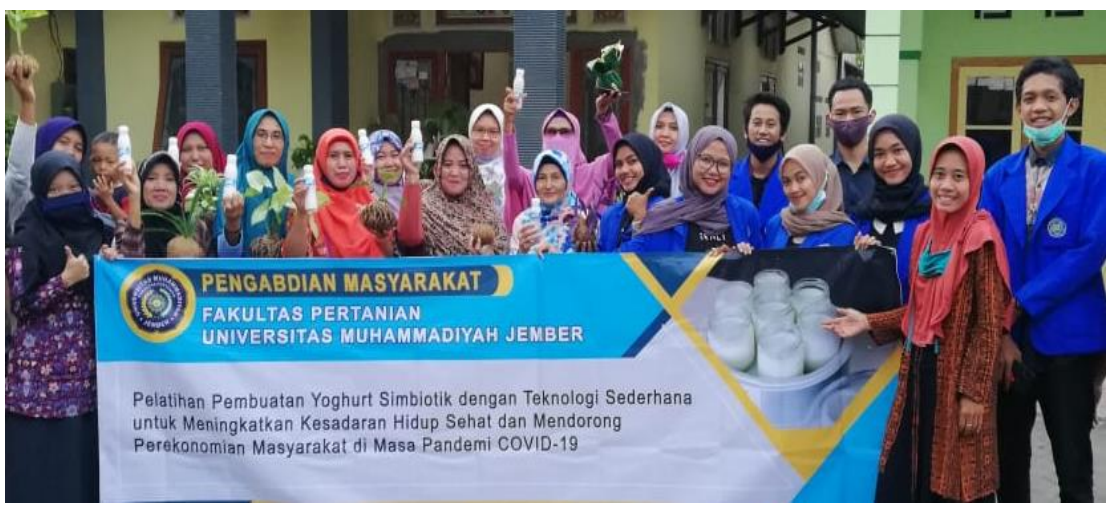

Gambar 4. Ibu-ibu PKK Desa Kemuning Lor dengan Contoh Produk Yoghurt yang sudah siap konsumsi

\section{3) Pelatihan manajemen bisnis dan pemasaran}

Pelatihan manajemen bisnis dan pemasaran bagi ibu-ibu PKK di Desa Kemuning Lor bertujuan untuk membina dan mengembangkan potensi produk susu sapi segar dan buah naga merah yang berada di daerah tersebut. Pembinaan dilakukan melalui berbagai pelatihan penerapan manajemen bisnis dari proses pengolahan, pengemasan, hingga pemasaran produk sehingga produk bernilai ekonomi tinggi dan dapat meningkatkan penghasilan warga sekitar.

Manajemen bisnis yang dilakukan berupa usaha pengelolaan secara optimal penggunaan sumber daya (atau sering disebut faktor produksi), tenaga kerja, peralatan, bahan mentah dan sebagainya dalam proses transformasi bahan mentah dan tenaga kerja menjadi berbagai produk atau jasa. Mitra sebagai manajer produksi dan operasi mengarahkan berbagai masukan (input) agar dapat memproduksi berbagai keluaran (output) dalam jumlah, kualitas, harga, waktu, dan tempat tertentu sesuai dengan permintaan konsumen.

Produksi susu sapi segar dan buah naga yang melimpah di Desa Kemuning Lor cukup menjanjikan dalam peningkatkan kesejahteraan warga. Produk yogurt sinbiotik yang berfungsi sebagai minuman fungsional dan produk ready to drink akan menjadi daya tarik tersendiri bagi konsumen khususnya untuk kawasan yang dinobatkan sebagai desa wisata Rembangan di Kabupaten Jember.

Pada kegiatan pengabdian juga dilakukan pelatihan perhitungan keuangan untuk penjualan yoghurt sinbiotik buah naga merah, berikut adalah hasil analisis keuangan yang sudah disampaikan dalam pengabdian.

Tabel 3 Daftar Rincian Biaya Bahan Pembuatan Yoghurt Sinbiotik Buah Naga Merah 


\begin{tabular}{|c|c|c|c|}
\hline NO & BAHAN & JUMLAH & HARGA \\
\hline 1 & SUSU SEGAR & 1 liter & Rp. 11.000 \\
\hline 2 & STATER (BIOKUL) & $80 \mathrm{ml}$ & Rp. 8.000 \\
\hline 3 & BUAH NAGA MERAH & $1 \mathrm{buah}$ & $\mathrm{Rp} 7.000$ \\
\hline 4 & GULA & $0.5 \mathrm{~kg}$ & Rp. 6.500 \\
\hline 5 & BOTOL & $10 @ 100 \mathrm{ml}$ & Rp. 15.000 \\
\hline 6 & LABEL & $1 \mathrm{lbr}$ & Rp. 9.000 \\
\hline \multicolumn{2}{|c|}{ Total } & Rp. 56.500 \\
\hline
\end{tabular}

Berdasarkan data di atas untuk 1 liter susu dapat dibuat menjadi 10 botol dengan ukuran $100 \mathrm{ml}$. sehingga perhitungan harga jual dapat dirumuskan seabagai berikut:

Penentuan harga jual 1 botol yogurt $=\frac{\text { Total Biaya }}{\text { banyaknya } \text { yogurt yang akan dijual }}=\frac{R p .56 .500}{10}$

$$
=R p .5 .650
$$

Sehingga, harga jual yogurt yaitu sebesar Rp. 5.650 atau bisa dibulatkan menjadi Rp 6.000 dengan margin keuntungan Rp 350,-/ botol

Proyeksi laba atau untung yang didapatkan dari 10 botol yogurt dengan 1 liter susu yaitu

$$
\begin{aligned}
& \text { Laba }=\text { Harga Jual }- \text { Total Biaya } \\
& \quad=(10 \times R p .6000)-R p .56 .500 \\
& \quad=R p .60 .000-R p .56 .500=R p .3 .500
\end{aligned}
$$

Jadi, laba atau untung yang didapat sebesar Rp. 3.500 per sepuluh botol.

\section{4) Evaluasi keberlanjutan}

Produksi susu sapi segar dan buah naga yang melimpah di Desa Kemuning Lor dapat meningkatkan kesejahteraan warga sekitar dengan cara mengolahnya menjadi produk yang memiliki nilai gizi tinggi. Produk yogurt sinbiotik buah naga merah dapat dijadikan sebagai produk andalan khususnya untuk kawasan yang dinobatkan sebagai desa wisata Rembangan di Kabupaten Jember.Kegiatan pelatihan pembuatan yoghurt sinbiotik mampu menciptakan sumber pendapatan bagi para petani dan warga sekitar Desa Kemuning Lor.Tim pengabdian mendampingi ibu-ibu PKK dalam memproduksi yogurt sinbiotik buah naga merah selama 3 bulan berturut-turut.

\section{KESIMPULAN DAN SARAN}

Melalui pelatihan dan pendampingan pengolahan yogurt sinbiotik, masyarakat yang diwakili oleh ibu-ibu anggota PKK memiliki kesadaran tentang jenis minuman yang memiliki manfaat kesehatan dan mampu mengolah susu menjadi yogurt sinbiotik yang memiliki nilai gizi dan ekonomi tinggi, serta dapat dijadikan alternatif dalam meningkatkan pendapatan warga. Hasil produksi yogurt sinbiotik buah naga merah diharapkan dapat diterima oleh semua lapisan masyarakat.Selanjutnya, perlu dilakukan koordinasi secara berkesinambungan dari mitra dan warga binaan dengan koperasi desa untuk melakukan promosi produk yogurt sinbiotik.

\section{UCAPAN TERIMA KASIH}

Terima kasih kami sampaikan kepada Lembaga Penelitian dan Pengabdian Kepada Masyarakat Universitas Muhammadiyah Jember yang telah memberikan bantuan dana pengabdian internal periode 2020-2021. 


\section{DAFTAR PUSTAKA}

Kementerian Pertanian. (2016). Buku Outlook Komoditas Peternakan Susu Sapi. Pusat Data dan Informasi Pertanian. Jakarta

Badan Pusat Statistik (BPS). (2017). Produksi Susu Sapi Perah. https://www.bps.go.id/dynamictable/2015/12/23/1095/produksi-susu-perusahaan-sapiperah-2000---2017.html. diakses pada 23 Januari 2021

Jatimnet. (2020). Penjualan Susu Sapi Perah Turun 76 Persen. https://jatimnet.com. diakses pada 23 Januari 2021.

Profil Desa Kemuning Lor. (2015). Profil Desa Kemuning Lor Kecamatan Arjasa. Balai Desa Kemuning Lor. Jember

Tamime, A.Y. and R.K. Robinson.(2007). Yoghurt science and technology. 3rd ed. Abington, Cambridge, England: Woodhead Publishing Ltd, CRC Press, LLC, NW, USA

Weerathilake WADV, DMD Rasika, JKU Ruwanmali, dan MADD Munasinghe. (2014). The evolution, processing, varieties and health benefits of yogurt. International Journal of Scientific and Research Publication (4).

Wichienchot S, Jatupornipat M, dan Rastalla RA. (2010). Oligosacharides of pitaya (dragon fruit) flesh and their prebiotic properties. Food Chem 120: 850 - 857. DOI: 10.106/j.foodchem.2009.11.02.6. 